\title{
Combined effect of different plant nutrients of organic and inorganic sources on nutrient uptake and yield of groundnut crop
}

\author{
K. V. Nathiya* and V. Sanjivkumar \\ Department of Soil Science and Agricultural Chemistry, Tamil Nadu Agricultural University, Coimbatore-641003 \\ (Tamil Nadu), INDIA \\ *Corresponding author. E- mail: nathiyakv13@gmail.com
}

Received: March 31,2014 ; Revised received: August 26, 2014 ; Accepted: October 07, 2014

\begin{abstract}
A pot culture experiment was conducted to study the effect of combined use of organic manures with inorganic fertilizers on uptake of available nutrients and yield of groundnut crop at Tamil Nadu Agricultural College and Research Institute, Madurai during kharif season of 2008-2009. The experiment was laid out in completely randomized design (factorial) with two replications. Main pot treatments comprised of three types of manures viz, control $\left(\mathrm{M}_{0}\right)$, pressmud @ $5 \mathrm{t} \mathrm{ha}^{-1}\left(\mathrm{M}_{1}\right)$, vermicompost @ $2 \mathrm{t} \mathrm{ha}^{-1}\left(\mathrm{M}_{2}\right)$, farmyard manure @12.5 $\mathrm{t} \mathrm{ha}^{-1}\left(\mathrm{M}_{3}\right)$ and sub pot treatment comprised of 4 levels of $\mathrm{K}$ viz, $0\left(\mathrm{~K}_{0}\right), 100\left(\mathrm{~K}_{1}\right), 75\left(\mathrm{~K}_{2}\right)$ and $50 \mathrm{~kg}$ of $\mathrm{K}_{2} \mathrm{O} \mathrm{ha}^{-1}\left(\mathrm{~K}_{3}\right)$ with a recommended dose of fertilizer (RDF) respectively. The results revealed that highest nitrogen, phosphorus and potassium uptake of $1.01,0.96$ and $0.80 \mathrm{~g} /$ pot was recorded in the treatment that received $75 \mathrm{~kg} \mathrm{~K}_{2} \mathrm{O} \mathrm{ha}{ }^{-1}$ and Pressmud @ $5 \mathrm{t} \mathrm{ha}^{-1}\left(\mathrm{~K}_{1} \mathrm{M}_{1}\right)$ and in the pots which treatment received $\mathrm{K}_{1} \mathrm{M}_{1}$ showed the highest Haulm and pod yield of (28.25 and $24.5 \mathrm{~g} / \mathrm{pot})$ of groundnut crop respectively.
\end{abstract}

Keywords: Groundnut crop, Inorganic plant fertilizers, organic manures, Uptake of nutrients Yield

\section{INTRODUCTION}

Groundnut being one of the important crops in Madurai district grows well in Madukkur soil series which happened to be the major soil series in the district. The bulk of oil production in India is derived from groundnut, rapeseed, sesame, sunflower, soyabean, sunflower and other minor oilseed crops, and among these crops, groundnut (Arachis hypogaea L) is the most dominant annual crop widely cultivated (Rathore and Kamble, 2008). From the nutritional point of view, oilseeds are important not only because they provide essential fatty acids mainly, but also due to their nutritive value in terms of other nutrients like carbohydrates, proteins, minerals and fat soluble vitamins (Singh et al., 2011). About 76 per cent of the total oilseed production is used for edible purpose and the remaining for soap and lubrication products manufacture. Potassium occurs in the soil in varied form viz, water soluble $\mathrm{K}$, exchangeable $\mathrm{K}$ (Kex), non-exchangeable $\mathrm{K}$ (Knex), mineral lattice $\mathrm{K}$ and total K. Because of the existence of different forms of $\mathrm{K}$, compared to $\mathrm{N}$ and $\mathrm{P}$ its availability is reported to be complicated (Malligawad et al. 2000). The varied forms of potassium responsible for the availability and maintaining of potassium equilibrium in the soil, has been discussed by many scientists. Even though soils contain considerable amount of total $\mathrm{K}$, the releasing and supplying power of soils in a given time is a limiting factor in most of the soils. The $\mathrm{K}$ releasing power of soils depends on number of factors, namely nature of soils, amount and type of clay minerals, $\mathrm{CEC}$, soil $\mathrm{pH}$ and level of manuring. Keeping in view, the present investigation was undertaken to study the combined effect of different plant nutrients of organic and inorganic sources on nutrient uptake and yield of ground crop.

\section{MATERIALS AND METHODS}

A pot culture experiment was conducted at TamilNadu Agricultural College and Research Institute, Madurai during kharif season of 2008-2009 to study the release of $\mathrm{K}$ in soil in relation to organic manures in Groundnut (TMV.7). Earthen pots with top diameter of $35 \mathrm{~cm}$, bottom diameter of $16 \mathrm{~cm}$ and height $28 \mathrm{~cm}$ were deaned and a layer of sand were placed at the bottom of each pot to provide drainage and aeration of roots. $20 \mathrm{~kg}$ of soil samples were transferred in those pots with gentle tapping on top 3" height for compacting the soil. A factorial completely randomized design was adopted with 4 levels of inorganic and organic each at $0,50,75,100 \mathrm{~kg} \mathrm{ha}^{-1}$, randomized and replicated two times. Factor A. -4 levels of $\mathrm{K}$ (Inorganic $\mathrm{K}$ fertilizers) $1.0 \mathrm{~kg} \mathrm{~K}_{2} \mathrm{O} \mathrm{ha}^{-1}$ (control) $\left(\mathrm{K}_{0}\right), 100 \mathrm{~kg} \mathrm{~K}_{2} \mathrm{O} \mathrm{ha}{ }^{-1}\left(\mathrm{~K}_{1}\right)$, $75 \mathrm{~kg} \mathrm{~K}_{2} \mathrm{O} \mathrm{ha}^{-1}\left(\mathrm{~K}_{2}\right), 50 \mathrm{~kg} \mathrm{~K}_{2} \mathrm{O} \mathrm{ha}^{-1}\left(\mathrm{~K}_{3}\right)$, Factor B.- 4 levels of (compost) control $\left(\mathrm{M}_{0}\right)$, pressmud @ $5 \mathrm{t} \mathrm{ha}^{-1}$ $\left(\mathrm{M}_{1}\right)$, vermicompost @ $2 \mathrm{t} \mathrm{ha}^{-1}\left(\mathrm{M}_{2}\right)$, farmyard manure 
@ $12.5 \mathrm{t} \mathrm{ha}^{-1}\left(\mathrm{M}_{3}\right)$. A bunch type groundnut (TMV. 7) was used as test crop. All the pots received uniform doses of $\mathrm{N}(17 \mathrm{~g})$ and $\mathrm{P}_{2} \mathrm{O}_{5}(34 \mathrm{~g})$. The entire quantity of phosphorus and a part of nitrogen was applied in the form of diammonium phosphate and the balance of nitrogen as urea. The calculated quantities of $\mathrm{K}$ as $\mathrm{KCl}$ and organic sources as pressmud, vermicompost, and farmyard manure. The fertilizers were mixed properly and moistened at optimum level and left as such for 3 days attain equilibrium. Groundnut seeds (TMV.7) were sown in the pots at the rate of five seeds per pot and three plants alone are allowed to grow after germination. Each pot periodically received the water uniformly based on the soil wetting and drying. Prophylatic measures against pests and diseases were taken regularly. Stagewise collected plant sample were analysed in laboratory for nutrient content (Total N, P and $\mathrm{K}$ ) and calculated the nutrient uptake expressed in $\mathrm{kg} \mathrm{ha}^{-1}$. The harvested pod yield were recorded and expressed in $\mathrm{g} / \mathrm{pot}$. The recorded data was statistically analysed ( Gomez and Gomez ,1984).The Nutrient uptake was calculated as follows:

Nutrient uptake $\left(\mathrm{kg} \mathrm{ha}^{-1}\right)=$ 100

\section{RESULTS AND DISCUSSION}

Nutrient uptake at different stages of crop growth Nitrogen uptake: The nitrogen uptake of groundnut was significantly influenced by the integrated and sole application of various organic sources. The highest nitrogen uptake of $1.01 \mathrm{~g} / \mathrm{pot}$ was recorded in the treatment that received $75 \mathrm{~kg} \mathrm{~K}_{2} \mathrm{O} \mathrm{ha}{ }^{-1}$ and pressmud @ $5 \mathrm{t} \mathrm{ha}^{-1}\left(\mathrm{~K}_{1} \mathrm{M}_{1}\right)$ which was found to be on par when applied with (0.99 g/pot ) $75 \mathrm{~kg} \mathrm{~K}_{2} \mathrm{O} \mathrm{ha}^{-1}$ along with farmyard manure @ $12.5 \mathrm{t} \mathrm{ha}^{-1}\left(\mathrm{~K}_{1} \mathrm{M}_{2}\right)$ and (0.98 g/pot) $\mathrm{K}_{1} \mathrm{M}_{3}-75 \mathrm{~kg} \mathrm{~K}_{2} \mathrm{O} \mathrm{ha}^{-1}$ along with vermicompost @ $2 \mathrm{t} \mathrm{ha}^{-1}$ whereas the lowest nitrogen uptake of $0.72 \mathrm{~g} /$ pot was recorded in control (Table.1). Significant increase in the uptake of nitrogen by plants was observed by the application of nutrients through pressmud and inorganic fertilizers. It might be due to the greater availability of nitrogen in soil which enhanced the growth of plants and ultimately led to higher accumulation of nutrients in their parts along with the highest total uptake. The enhanced release of nitrogen from the organic sources increases the nitrogen uptake by groundnut crop. The effect of $\mathrm{K}$ levels on the uptake of nitrogen in pod and haulm reveled that at $\mathrm{K}_{1} \mathrm{M}_{1}$ level favoured the uptake of $\mathrm{N}$ in pod and haulm respectively. This might be ascribed to the increased availability of $\mathrm{N}$ at these levels of $\mathrm{K}$ application. Increased level of $\mathrm{K}$ promoted the $\mathrm{K}$ uptake. Parihar and Pathan (2004) and Roy and Singh (2006) studied that application of organic and inorganic fertilizers were increased the nutrient uptake might be due to the combined effect of organic and inorganic fertilizers on the increased nutrient availability and microbial activity resulting in better nutrient absorption and growth of crops. Laxminarayanan (2004) reported that integrated application of organic and inorganic manures showed higher uptake of nitrogen, phosphorus and potassium compared to sole application of organic manure due to increased nutrient availability.

Phosphorus uptake: The highest phosphorus uptake of $0.96 \mathrm{~g} /$ pot was recorded in treatment which received $\left(\mathrm{K}_{1} \mathrm{M}_{1}\right) 75 \mathrm{~kg} \mathrm{~K}_{2} \mathrm{O} \mathrm{ha}{ }^{-1}$ and Pressmud @ $5 \mathrm{t} \mathrm{ha}^{-1}$ and it was found to be significantly superior to the rest of treatments involving integrated and sole application of organic sources (Table 1). The results of statistical analysis showed that the uptake of phosphorus by maize was significantly influenced by integrated and sole application of organic and inorganic sources. The result substantiates the findings of many researchers, Increase in soil available nutrients and nutrient $(\mathrm{N}, \mathrm{P}$ and $\mathrm{K}$ ) uptake were reported due to application of Pressmud along with the recommended dose of fertilizers (Rajkhowa et al., 2000). Talathi et al. (2009) studied that total uptake of N, P, K by the crops increase significantly with the increased in the dose of fertilizers over control whereas combined use of inorganic fertilizers registered the highest value with organic manures.

Potassium uptake: The potassium uptake by maize

Table 1. Uptake of nitrogen, phosphorus, potassium by groundnut.

\begin{tabular}{lccc}
\hline Treatments & $\begin{array}{c}\text { Nitrogen } \\
\text { uptake } \\
\text { (g/pot) }\end{array}$ & $\begin{array}{c}\text { Phosphorus } \\
\text { uptake } \\
\text { (g/pot) }\end{array}$ & $\begin{array}{c}\text { Potassium } \\
\text { uptake } \\
\text { (g/pot) }\end{array}$ \\
\hline K0M0 & 0.72 & 0.65 & 0.55 \\
K0M1 & 0.75 & 0.68 & 0.58 \\
K0M2 & 0.74 & 0.67 & 0.57 \\
K0M3 & 0.73 & 0.66 & 0.56 \\
K1M0 & 0.98 & 0.90 & 0.79 \\
K1M1 & 1.01 & 0.96 & 0.80 \\
K1M2 & 0.99 & 0.94 & 0.78 \\
K1M3 & 0.98 & 0.92 & 0.76 \\
K2M0 & 0.90 & 0.86 & 0.70 \\
K2M1 & 0.94 & 0.89 & 0.72 \\
K2M2 & 0.93 & 0.87 & 0.72 \\
K2M3 & 0.92 & 0.85 & 0.71 \\
K3M0 & 0.89 & 0.76 & 0.72 \\
K3M1 & 0.88 & 0.78 & 0.70 \\
K3M2 & 0.87 & 0.75 & 0.72 \\
K3M3 & 0.86 & 0.74 & 0.71 \\
SEd (K) & 0.0021 & 0.0042 & 0.0012 \\
CD( P = 0.05 ) & 0.004 & 0.0834 & 0.0245 \\
SEd ( N ) & 0.0021 & 0.0042 & 0.0012 \\
CD ( P = 0.05 ) & 0.0045 & 0.0834 & 0.0245 \\
SEd ( K X N) & 0.0045 & 0.0834 & 0.0245 \\
CD ( P =0.05 ) & 0.0086 & 0.1648 & 0.0438 \\
\hline & & &
\end{tabular}


Table 2. Haulm yield (g/pot) and pod yield (g/pot) of groundnut with different treatments.

\begin{tabular}{lcc}
\hline Treatment & $\begin{array}{c}\text { Haulm yield } \\
\text { (g/pot) }\end{array}$ & Pod yield (g/pot) \\
\hline K0M0 & 17.60 & 16.5 \\
K0M1 & 20.08 & 17.5 \\
K0M2 & 18.67 & 16.8 \\
K0M3 & 19.59 & 16.5 \\
K1M0 & 24.95 & 22.5 \\
K1M1 & 28.25 & 24.5 \\
K1M2 & 26.25 & 23.6 \\
K1M3 & 26.65 & 22.8 \\
K2M0 & 24.37 & 20.5 \\
K2M1 & 25.45 & 21.4 \\
K2M2 & 24.65 & 20.8 \\
K2M3 & 24.58 & 19.5 \\
K3M0 & 23.56 & 19.6 \\
K3M1 & 23.89 & 19.4 \\
K3M2 & 22.64 & 18.0 \\
K3M3 & 22.72 & 18.5 \\
SEd (K) & 1.56 & 1.43 \\
CD( P = & 2.96 & 2.80 \\
0.05 ) & & \\
SEd ( N ) & 1.56 & 1.43 \\
CD & 2.96 & 2.83 \\
(P $=0.05 ~$ & & \\
SEd & 2.96 & 2.83 \\
K X N) & & \\
CD & 5.50 & \\
( P =0.05 & & \\
\hline
\end{tabular}

plant varied from 0.55 to $0.80 \mathrm{~g} / \mathrm{pot}$. The highest potassium uptake of $0.80 \mathrm{~g} /$ pot was recorded in the treatment that received $\left(\mathrm{K}_{1} \mathrm{M}_{1}\right) 75 \mathrm{~kg} \mathrm{~K}_{2} \mathrm{O} \mathrm{ha}^{-1}$ and pressmud @ $5 \mathrm{t} \mathrm{ha}^{-1}$ and it was followed by the sole application $75 \mathrm{~kg} \mathrm{~K}_{2} \mathrm{O} \mathrm{ha}{ }^{-1}$ with a value of $0.79 \mathrm{~g} / \mathrm{pot}$ respectively. Lowest value recorded in the control pot (Table. 1). This could be ascribed to the accumulation of dry matter content in plant in the above treatment warranting higher potassium uptake. Availability of nitrogen increased the uptake of potassium. This particular treatment could have increased the exchangeable and water soluble potassium and by supplying inorganic nutrients too. Roy and Singh (2006) reported that treatments involving pressmud either alone or in combination with RDF were recorded significantly higher potassium uptake by wheat over RDF and burning of wheat straw + RDF.
Singh et al. (2008) studied that application of enriched compost along with inorganic fertilizers were releasing $\mathrm{N}, \mathrm{P}$ and $\mathrm{K}$; and particularly improving potassium uptake in soil. Prasad et al., 2010 reported that integrated nutrient management practices recorded significantly higher uptake of N, P and K by the kharif and rabi crops when compared to inorganic and organic nutrient management practices. The response of crops to integrated nutrient management is due to higher availability of these nutrients in soil reservoir besides the additional quantity of nutrients supplied by FYM and inorganic fertilizers. This was ascribed to continuous supply of $\mathrm{N}, \mathrm{P}$ and $\mathrm{K}$ throughout the crop growth periods as the nutrients from inorganic sources were available to the crop in the early stages and in the later stages of the crop growth, the slow and continuous release of nutrients from the organic source made available.

Effect of organic and inorganic manures on yield of groundnut crop: The results of statistical analysis showed that the yield of groundnut significantly influenced by the application of organic and inorganic sources. The mean value of haulm ranged from 16.50 to $24.50 \mathrm{~g} \mathrm{pot}^{-1}$. The yield of groundnut was significantly influenced by application of various sources of organic manures. The result revealed that the pots which received $75 \mathrm{~kg} \mathrm{~K}_{2} \mathrm{O} \mathrm{ha}^{-1}$ and Pressmud @ $5 \mathrm{t} \mathrm{ha}^{-1}$ $\left(\mathrm{K}_{1} \mathrm{M}_{1}\right)$ showed the highest haulm and pod yield of ( 28.25 and $24.5 \mathrm{~g} / \mathrm{pot}$ ) of groundnut crop respectively and it was followed by the application of $75 \mathrm{~kg} \mathrm{~K}_{2} \mathrm{O} \mathrm{ha}{ }^{-1}$ $\left(\mathrm{K}_{1} \mathrm{M}_{0}\right)$ with the value of haulm yield and in pod yield in $\left(\mathrm{K}_{1} \mathrm{M}_{2}\right) 75 \mathrm{~kg} \mathrm{~K}_{2} \mathrm{O} \mathrm{ha}^{-1}$ (26.25) along with the application of vermicompost @ $2 \mathrm{t} \mathrm{ha}^{-1}(23.6 \mathrm{~g} / \mathrm{pot})$ (Table 2). The lowest value registered in the control pots. Addition of $\mathrm{K}$ to soils apart from increasing the available K status, also favour higher pod yield which might be mediated possibly due to the increased nitrogen use efficiency with increasing levels of $\mathrm{K}$ resulting higher biomass production was observed by Patel et al. (2010).The application of K had marked benefit in increasing the pod yield. Potassium helps in the synthesis of sugars and starch and also in the resistance to the crops against pest and diseases which in turn, increased the yield. It was evident from the results, the increasing level of $\mathrm{K}$ resulted in simultaneous increase of biometric and yield attributes except the number of unfilled pods which decreased considerably for the graded doses of $\mathrm{K}$ application. The different levels and split application of potassium

Table 3. Co- efficient of correlation between different forms of K.

\begin{tabular}{lccccc}
\hline Forms of K & $\mathbf{H}_{2} \mathbf{O}$ sol K & Exchangeble K & Non-Exchangeable K & Lattice K & Total K \\
\hline $\mathrm{H}_{2} \mathrm{O}$ sol K & 1 & $0.529^{*}$ & 0.394 & NS & NS \\
Kex & & 1 & $0.736^{* *}$ & NS & NS \\
Knex & & 1 & NS & $0.407^{* *}$ \\
Lattice K & & & & 1 & $0.994^{* * *}$ \\
Total & & & & & 1 \\
\hline
\end{tabular}

** Significant at 5\% level, *** Highly significant at 5\% level, NS - Non -significant. 
was also found to increase the number of pods in plants Krishnappan et al. (1990). The supply of K to the crop during crop growth period is considered to be more beneficial increase the total number of pods dry matter accumulation and weight of pods. Meena et al. (2003) studied that groundnut yield increased with soil application of the higher doses of the fertilizers along with integrated application of manures.

Co-efficient correlation between different forms potassium: The lattice $\mathrm{K}$ was highly correlated $\left(\mathrm{r}^{2}=0.994 * * *\right)$ with total $\mathrm{K}$ where the highest amount of $\mathrm{K}$ is fixed in the hexagonal cavities of the clay mineral and released when the non-exchangeable $\mathrm{K}$ source is depleted. Hence, the non-exchangeable $\mathrm{K}$ was positively correlated with lattice $\mathrm{K}\left(\mathrm{r}^{2}=0.309^{*}\right)$ and total $\mathrm{K} \quad\left(\mathrm{r}^{2}=0.407^{* *}\right)$. The exchangeable $\mathrm{K}$ and non-exchangeable are highly correlated $\left(r^{2}=0.736 * *\right)$, it denotes that dynamic equilibrium exists between these two forms of $\mathrm{K}$ in the soils. The similar dynamic equilibrium also exists between water soluble $\mathrm{K}$ and non-exchangeable $\mathrm{K}\left(\mathrm{r}^{2}=0.529 *\right)$ and water soluble $\mathrm{K}$ and exchangeable $\mathrm{K}\left(\mathrm{r}^{2}=0.394\right)$ (Table. 3$)$. The positive correlation results obtained from the forms of soil potassium indicates the existence of dynamic equilibrium among all the forms of soil potassium.

\section{Conclusion}

The present study, concluded that highest nitrogen, phosphorus, potassium uptake and haulm and pod yield was found supremacy with the treatment that received $75 \mathrm{~kg} \mathrm{~K}_{2} \mathrm{O} \mathrm{ha}{ }^{-1}$ and pressmud @ $5 \mathrm{t} \mathrm{ha}^{-1}$ then rest of the treatment tried in groundnut crop respectively. Applying of organic plant nutrients along with inorganic fertilizers in the soil, the complexing properties of organic materials which prevented the precipitation and fixation of nutrients and kept them in soluble form. The solubilization action of organic acids produced during the degradation of organic materials resulted in better release of the essential nutrients in the soil ecosystem and effectively utilized by the plants for their growth and development and also sustaining the soil quality.

\section{ACKNOWLEDGEMENTS}

This research was conducted in Tamil Nadu Agricultural University, Coimbatore, Tamil Nadu state. I gratefully acknowledge the chairman, Prof. Dr. G. Jamespitchai who guided me during the experiments and I thank my family members and friends circle also, who have helped me directly and indirectly.

\section{REFERENCES}

Gomez, K. A and Gomez, A. A. (1984). Statistical procedures for Agricultural Research., John Wiley and Sons, New Delhi. pp. 680.

Krishnappan, M., Narayana Gowda, K., Shankaranarayan, V., Maharudrappa, K. and Khan, M. M. (1990). Effect of graded levels and split application of potassium on its availability and yield of rice. J. Pot .Res., 6(4):156161.

Laxminarayanan, K. (2004). Effect of organic and inorganic manures on yield and nutrient uptake of groundnut (Arachis Hypogaea L.) in utisols of Mizoran. J. of Oil Seeds Res., 21(2): 280-283.

Malligawad, L. H., Patil, R. K., Vidyadhar, K. and Giriraj, K. (2000). Effect of fertility management practices in groundnut. Karnataka J. Agril. Sci., 13(2) : 299-305.

Meena, S. L., Singh, S. and Shivraj, Y. S. (2003). Response of hybrid rice to nitrogen and potassium application in sand clay loam soils. Indian J. Agri. Sci., 73 (1):811

Parihar, N.S. and Pathan, A.R.K. (2004). Effect of sulphur, zinc and organic manures on yield, quality and uptake of nutrients by wheat. Ann. Pl. Soil Res., 6 (2):162165.

Patel, C. K., Chaudhari, P. P., Patel, R. W. and Patel, N. H. (2010). Integrated nutrients management in potato based cropping systems in north Gujarath. Potato J., 37(1-2) : 68-70.

Prasad, J., Kadamkar, S., Kumar, R. and Mishra, B. ( 2010). Influence of integrated nutrient management on yield and soil properties in maize-wheat cropping systems in an Alfisol of Jharkhand. J. Indian Soc. Soil Sci., 58 (2) : 200-204.

Rajkhowa, D. J., Gogoi, A. K., Kandhali, R. and Rajkhowa, K.M. (2000). Effect of vermicompost on groundnut nutrition. Ann. Agric. Res. New Series. 24(1): 73-77.

Rathore, P. K. and Kamble, B. M. (2008). Integrated nutrient management in summer groundnut. Adv. Plant Sci., $21: 329-331$.

Roy, D. K and Singh, B. P. (2006). Effect of level and time on nitrogen application with without vermicompost on yield, yield attributes and quality of malt barley. Indian J.Agron.,51(1): 40-42.

Singh, A. B., Saha, J. K. and Gosh, P. K.(2008). Effect of nutrient management practices on soybean (Glycine max), chickpea (Cicer arietinum) cropping systems for improving seed yield, quality and soil biological health under rainfed condition. Indian J. Agric. Sci., 78(6) : 485-489.

Singh, G. P., Singh, P. L. and Panwar, A. S. (2011). Response of groundnut (Arachishypogaea) to biofertilizers, organic and inorganic sources of nutrient in North-East India. Legume Res. 34 : 196-201. 